\title{
STIPENDIARIES OF THE CALVINIST CHURCH OF THE GRAND DUCHY OF LITHUANIA AND ITS SYNOD IN FOREIGN UNIVERSITIES IN THE 17TH CENTURY
}

\author{
Ingè Lukšaité
}

\begin{abstract}
The article analyses the organisation of higher education by the Calvinist Church of the Grand Duchy of Lithuania (Unitas Lituaniae) in the 17th century, in the period of the weakening of the Reformation, covering the first half of the 17th century, and the second half of the century, when Evangelicals became a religious minority. Research reveals that the education of young people at foreign universities was funded by private means, collected in the districts and accumulated by the Synod. This article also investigates the formation of the institution of international alumni at the Synod of the Calvinist Church, which became part of the system of education of that Church. The stipendiaries had to make up for the financial aid by working at locations assigned by the Synod. The continuous operation of the institute of international alumni at the Synod for more than a century permitted cultural contacts and simultaneously promoted the infusion of new ideas into the evolution of Lithuanian culture. The most important of the latter included the formation of groups of clergymen and school teachers with a university education; the nurturing of Adomas Rasijus' (ca 1575-1627/8) projects for the adjustment of the social structure and the refinement of the education system in Lithuania by the establishment of academic grammar schools for the nobility and merchants from Lithuania with special syllabi; the encouragement of S.B. Chylinski to translate the Bible into Lithuanian in the middle of the 17th century in Franeker and London; understanding the importance of the Lithuanian language as a written language and the language of the Holy Scripture; the possibility to get acquainted with the translation, text and commentaries of the Dutch Statenbijbel; the encouragement to complete the translation of the New Testament into the Lithuanian language and publish it in 1701; planning the translation of a commentary to the Dutch Statenbijbel into Polish.
\end{abstract}

Research into the stipendiaries of the Synod of the Calvinist Church of Lithuania in foreign universities in the 17th century is connected with S.B. Chylinski's translation of the Bible into the Lithuanian language and the 350th anniversary of its publication. First and foremost, the relevance of this connection is supported by the fact 
that Samuel Bogusław Chylinski (ca 1633-66) himself was one of the Synod's stipendiaries. Secondly, Chylinski's translation was a consequence of the interaction of Lithuanian, Dutch and English cultures, and the stipendiaries served as mediators of cultural connections, who established and nurtured contacts. Thus, it is important to understand what their input into Lithuanian culture was. This topic is part of a much wider class of questions, including cultural connections and interactions among European countries, the history of European mentalites, the evolution of higher education, and many more.

Studies that analyse different topics relating to the development of the Reformation in Lithuania refer to the education of students from the Calvinist Church of the Grand Duchy of Lithuania (GDL) at foreign universities from various angles. The academic trips by GDL Calvinists to European universities is a research topic that would facilitate answers to more extensive questions, as the Calvinist community in Lithuania was an influential religious, social and cultural power well into the mid-17th century. The period between ca 1575 and 1610 saw a balance between the authority of the Calvinist and Roman Catholic Churches, as the network of Calvinist parishes covered about half of former Catholic parishes, and Calvinists held more than half of the state's top offices and made up almost half of the GDL's senators. The Calvinist Church was the most numerous and most influential trend of the Reformation that formed in the GDL. Even though, starting with the 1610s, the Calvinist community started weakening, it remained a power affecting cultural processes in the country well into the middle of the century.

Since the early 20th century, historians have analysed the education of young people from the Polish-Lithuanian Commonwealth at foreign universities from various aspects. Teodor Wotschke was among the first historians to study the education of young people from the Polish-Lithuanian Commonwealth (which he refers to as Poland) at the universities of Wittenberg, Heidelberg, Altdorf, Frankfurt (Oder), Königsberg, Leipzig and Leiden. ${ }^{1}$ One of the first Lithuanian historians to approach the issue of education at foreign

${ }^{1}$ Teodor Wotschke, 'Polnische Studenten in Wittenberg', Jahrbücher für Kultur und Geschichte der Slaven, 2 (1926), pp. 169-200; idem., 'Polnische Studenten in Heidelberg', ibid., pp. 46-67; idem., 'Polnische Studenten in Leiden', ibid., 3 (1927), pp. 461-86; idem., 'Polnische Studenten in Altdordf', ibid., 4 (1928), pp. 216-32; idem., 'Polnische Studenten in Frankfurt', ibid., 5 (1929), pp. 228-44; idem., 'Polnische Studenten in Leipzig', ibid., 7 (1931), pp. 61-81; idem., 'Polnische und litauische Studenten in Königsberg', ibid., 6 (1930), pp. 428-47. 
universities from a general aspect, without attempts to distinguish between confessions, was A. Šapoka. ${ }^{2}$ Vaclovas Biržiška analysed the extent of academic trips, and published the most exhaustive lists of students from the GDL educated at European universities, including the ones prepared by the Polish scholar S. Kot. ${ }^{3}$ Unfortunately for all of us commemorating the 350th anniversary of the publication of Chylinski's Bible, the most important lists of students, including the register of GDL students at Franeker University, attended by Chylinski, are missing. Apparently, this part of Biržiška's manuscript was lost in 1944 during his emigration from Lithuania. In the second half of the 20th century, historians strove to perceive the extent of the phenomenon, thus focusing on the universities favoured by the GDL's students, and the statistics revealing how many students were educated at certain institutions. Most attention was paid to studies at the University of Cracow, analysed by Marcelinas Ročka, the Belarusian scholar Georgii Golenchenko, the Cracovian Wacław Urban, and Sigitas Lūžys, to name but a few. ${ }^{4}$ For the most part, they based their research on data from university matriculation books, which, despite certain inaccuracies, helped give a general view of the issue. Lithuanian cultural historians who studied the lives and works of renowned Lithuanian personalities, such as S. Rapolionis, A. Kulvietis, M. Mažvydas, A. Volanus, the Radvilas, and others, analysed what role the education of Lithuanian citizens at the universities of Central and Western Europe played in the evolution of the country's culture, and what possibilities it provided for the interaction of the GDL and other cultures on the mentality level. ${ }^{5}$

${ }^{2}$ Adolfas Šapoka, 'Kur senovejje lietuviai mokslo ieškojo?', Židinys (1935), no. 10 , pp. 316-430.

${ }^{3}$ Vaclovas Biržiška, Lietuvos studentai užsienio universitetuose XIV-XVIII amžiais, ed. M. Biržiška, A. Šapoka (Chicago, 1987).

${ }^{4}$ Marcelinas Ročka, 'Lietuviu studentai Krokuvoje ir humanizmo pradžia Lietuvoje (XV-XVI a. pradžia)', idem, Rinktiniai raštai (Vilnius, 2002) pp. 4370; G. Golenchenko, 'Studenty Velikogo Kniazhestva Litovskogo v Krakovskom universitete v XV-XVI vv.' Kul'turnye sviazi narodov vostochnoi Evropy v XVI v. (Moscow, 1976); W. Urban, Cracovia lithuanorum saeculis XIV-XVI // Lietuviu Krokuva XIV-XVI amžiais (Vilnius, 2000).

${ }^{5}$ Stanislovas Rapolionis, ed. E. Ulčinaitè, J. Tumelis (Vilnius, 1986); D. Pociūtè, Maištininku katedros. Ankstyvoji reformacija ir lietuviu-italu evangeliku ryšiai (Vilnius, 2008), pp. 57-93; eadem, 'Abraomas Kulvietis ir pirmasis evangeliku tikèjimo išpažinimas Lietuvoje’, Abraomas Kulvietis: pirmasis Lietuvos reformacijos paminklas, ed. D. Pociūtè (Vilnius, 2011), pp. 11-20; A. Jovaišas, Martynas Mažvydas. Pirmosios lietuviškos knygos parengejjas (Vilnius, 1996); M. Ročka, ‘Andrius Volanas. Gyvenimas ir raštai’, Andrius Volanas, Rinktiniai raštai, ed. M. Ročka, I. Lukšaitè 
The works of the abovementioned researchers contain data analysed from matriculation records, supplemented with information obtained from the writings of former students from foreign universities, and conclusions based on an analysis of the evolution of attitudes, ideas and views. A considerable amount of attention is dedicated to the study of the nobility and the Calvinist branch of the Radvila family, high-ranking state officials, focusing especially on the most prominent personalities of the 17th century, Jonušas Radvila (Janusz Radziwiłł) and Kristupas Radvila (Krzysztof Radziwiłł). ${ }^{6}$ Educational trips by Lithuanian nobles to foreign universities and famous courts were of the utmost importance to the training of the political, economic and cultural elite in the 17 th century. R. Plečkaitis coherently analysed the role of education at foreign universities in the development of the science of philosophy. ${ }^{7}$ Less information is available on the international training of the fathers of Lithuanian literature or Protestant clergymen in the 17 th century, yet certain relevant issues have already been studied: Kot and others worked on Chylinski's biography, ${ }^{8}$ certain historians analysed the history of the Reformation in the GDL, ${ }^{9}$ and some scholars studied the history, translation and

(Vilnius, 1996), pp. 6-26; K. Daugirdas, Andreas Volanus und die Reformation im Grossfurstentum Litauen (Mainz am Rhein, 2008), pp. 19-25.

${ }^{6}$ M. Chachaj, Zagraniczna edukacja Radziwitłów od poczatku XVI do połowy XVII wieku (Lublin, 1995); H. Wisner, Janusz Radziwitt 1612-1655, Wojewoda wileński, hetman wielki litewski (Warsaw, 2000); T. Kempa, Mikołaj Krzysztof Radziwitt Sierotka (1549-1616), wojewoda wileński (Warsaw, 2000), p. 195.

${ }^{7}$ R. Plečkaitis, Lietuvos filosofijos istorija, I tomas: Viduramžiai-renesansasnaujieji amžiai (Vilnius, 2004).

${ }^{8}$ S. Kot, 'Geneza i tło historyczne Biblii Litewskiej Chylińskiego', Biblia litewska Chylińskiego. Nowy Testament, vol. 1: Tekst, ed. C. Kudzinowski, J. Otrębski (Poznań 1958), pp. ix-xxxii; I. Lukšaitė, 'Lietuviškos Chilinskio biblijos spausdinimo aplinkybės' Lietuvos TSR Mokslu akademijos darbai, A serija (MADA), 1(35) (1971), pp. 87-109; G. Kavaliūnaite, 'Samuelis Boguslavas Chylinskis ir jo Biblijos vertimas i lietuvių kalbą', Samuelio Boguslavo Chylinskio Biblija: Senasis Testamentas: Lietuviško vertimo ir olandiško originalo faksimilès, ed. G. Kavaliūnaitė (Vilnius, 2008), pp. xix-1xxi.

${ }^{9}$ J. Jurginis, Istorija ir poezija, Kultūros istorijos etiudai (Vilnius, 1969); S. Kot, 'La Réforme dans le Grand Duché de Lithuanie. Facteur d'occidentalisation culturelle', Extrait de l'Annuaire de l'Institut de Philologie et d'histoire orientales et slaves, XII, 1952. Mélanges Henri Grégoire (Brussels, 1953), pp. 211-61; H. Barycz, 'Obraz historyczny kalwinizmu na Litwie 1650-1696 r., Reformacja w Polsce, 4 (1926), pp. 206-21; M. Kosman, Reformacja i kontrreformacja w Wielkim Księstwie Litewskim w swietle propagandy wyznaniowej (Wrocław-Warsaw, etc., 1973); I. Lukšaite, Reformacija Lietuvos Didžiojoje Kunigaikštystëje ir Mažojoje Lietuvoje XVI a. trečias dešimtmetis - XVII a. pirmas dešimtmetis (Vilnius, 1999). 
publication of Knyga nobažnystès krikščioniškos. ${ }^{10}$ Ferenc Postma's work on the bibliography of theses defended by students of theology, medicine and law in the 16th and 17th centuries at Franeker University contains a great deal of new data. ${ }^{11}$ Thus, it can be stated that the first steps in the analysis of the significance of foreign studies on the interpretation of the evolution of cultural history in the 16th and 17th centuries have been made: the approximate extent of education at foreign universities has been disclosed, the role of such studies in the development of certain branches of science, such as philosophy, and the formation of certain political and cultural attitudes, as well as the shaping of the mentality of those with high levels of literacy, have been analysed, and the extent of their studies at particular universities has been researched. Even though a great deal of information on international studies in the 17th century has been accumulated, it remains scattered. This article focuses on one group of students, namely Lithuanian Calvinist stipendiaries, sent abroad by one institution.

Lithuanian Calvinist stipendiaries have not previously been considered as a separate group. Certain scholars have stated that there were Synod stipendiaries and others have collected data on studies at certain universities through analysis of personal biographies. This study is based on different primary sources, and thus offers a view on the international studies of Lithuanian students from a different angle. It aims at an analysis of the attitude of one Christian faith, Calvinism, in Lithuania towards education at foreign institutions, the identification of the universities popular among the young members of the Church, and casts a glance at the organisation of the educational process: who selected the people entitled to study abroad, how the financial resources were accumulated, what the numbers of young people eligible for international studies were, any differences in the implementation of the education plan at foreign universities in the 16th and 17th centuries, and how the education acquired expanded horizons and connections established benefited Lithuanian culture.

${ }^{10}$ D. Pociūte, 'Lietuviškosios bažnyčios knyga, Knyga nobažnystès krikščioniškos 1653, fascimile edition, ed. D. Pociūtė (Vilnius, 2004), pp. xiii-lxiv; I. Lukšaitè, 'Knygos nobažnystès (1653) parengimo kultūrinè aplinka', Knyga Nobažnystès krikščioniškos (1653) - XVII a. Lietuvos kultūros paminklas (Kèdainiai, 2001), pp. 12-16.

${ }^{11}$ F. Postma, J. van Sluis, Auditorium Academiae Franekerensis. Bibliographie der Reden, Disputationen und Gelegenheitssdruckwerke der Universität und des Athenäums in Franeker 1585-1843 (Leewarden, 1995). 
This study is based on records of the Lithuanian Calvinist Synod and data from the Synod's archive, thus internal church records form the basis of our research.

First of all, let us analyse how and why the Lithuanian Calvinist Church, Unitas Lituaniae, came to the establishment of an institution for the education of Synod stipendiaries at foreign universities. As we all know, Calvinists in Europe and Lithuania required a university education for their clergy. Candidates for the position of superintendent were required to hold an MA. Following three unsuccessful attempts $(1561,1565$ and 1588) to open a Protestant university in Vilnius ${ }^{12}$ and the establishment of Vilnius University by the Jesuits in 1579, the Lithuanian Calvinist Synod faced the need to make a decision regarding the organisation of higher education. In the last quarter of the 16th century, Lithuanian Calvinists adopted the practice of acquiring a university education abroad. Since the majority of the Synod's archive documents recorded before 1611 have perished, only attempts to organise international studies in the 17 th century can be subjected to more consistent analysis.

The data collected from records of university matriculation books suggest that there were several ways for young Calvinists to enter foreign universities: noblemen would use their own funds, their families would organise their trips and decide where and how long their offspring would study; gentlemen and burghers would frequently go as study instructors, supervisors or attendants to the noblemen, yet also often funded by their parents or patrons; the majority of them, however, would take the third way, a church scholarship. There were also three ways to obtain financial support from the Church: some were supported by a specific community, which needed a well-trained pastor; others were funded by the authorities of the district; and the third group received grants from the Synod. All the abovementioned ways facilitated the education of young Calvinists at foreign universities. However, going further into the evolution of the ways of funding, we face the question of whether they were of equal importance throughout the 17 th century.

As the Synod archive documents suggest, the institute of Synod stipendiaries was formed in the last quarter of the 16th century. This way of funding was the most centralised, had its advantages and disadvantages, and, importantly, was prompted by the chang-

${ }^{12}$ Lukšaitè, Reformacija, pp. 304-7, 468-70. 
ing situation of Calvinists in national society. How and when was it formed?

Starting with the 1610s, the situation of Unitas Lituaniae was gradually becoming more complex. The former balance between Catholics and Protestants changed in favour of the former, the Counter Reformation and especially the establishment of Vilnius University won over part of the Calvinist community, kings Sigismund and Wladyslaw Vasa, from a political point of view, openly favoured Catholics, and would appoint them to important and gainful offices. In the course of reforms, the Catholic Church filed suits against the Calvinist Church, to reclaim churches that had been turned into Protestant ones. Certain repressive actions were also observable: Catholic society organised religious unrest (in Vilnius in 1611 and 1639), attacked and set Protestant churches on fire. All the abovementioned factors motivated the nobility to convert to Catholicism. The decreasing numbers of Calvinists among the nobility led to a simultaneous decline of the communities under their patronage, put at risk their churches and reduced the financial resources of the Church and its influence on cultural processes in the GDL. The Calvinist Church took up a defensive position, but was still planning a number of positive steps. Starting with the 1610s, the leaders and patrons of Unitas Lituaniae plunged into an intensive search for ways to maintain its positions in Lithuanian society. In their opinion, the education of clergymen and teachers was one of the basic methods to retain their cultural and intellectual strength.

In the first quarter of the 17th century, when the Church was already feeling a decrease in the financial aid from the nobility, all its financial resources were accumulated carefully and invested, or managed in other ways by a person authorised by the Synod. Even though the data referring to the first quarter of the 17th century suggest that the nobility still funded the education of certain people amply, usually the children of the pastor in charge of their church, the Synod increased its accumulation of resources for international studies.

In the first half of the 17th century, the clergymen (parents) who recommended a student for education at a foreign university were responsible for his studies and work upon his return home; if the candidate was funded by the district, the responsibility was placed on the district's elders; and in cases when the student was funded by a particular church, for example the Vilnius parish, the responsibility 
rested on its clergymen and elders. The Synod's archive documents reveal that studies at foreign universities organised by the Church were a constituent part of their system of education, a natural continuation of secondary education acquired at home. Seminaries providing the training of young men to perform the functions of teachers and junior clergymen and preparation for studies at institutions of higher education, were in operation at certain Calvinist secondary schools by the last quarter of the 16th century. From 1625, about 40 people annually were entitled to train there. At the end of the 16th century, there was a grammar school in Vilnius and a specialised school (schola particularis) in Šiluva. In 1615, plans were made to establish a grammar school in Biržai, but they were abandoned due to the outbreak of the Livonian War. In the 1620s, the Synod's decrees provided for the establishment of two new schools with seminaries: in Kèdainiai for Lithuanian districts, and in Slutsk for Belarusian districts speaking the Ruthenian language. In 1654, another grammar school was opened in Zabludov. Excellent school-leavers ready to become pastors or undertake functions assigned by the Church could become the Synod's stipendiaries, which were called international alumni. The organisation of international training was continuously improved and adjusted to the changing situation of the Church in the country, and considered by the Church as a method to survive in the postwar period of the mid-17th century, which led to its becoming the church of a religious minority. From the middle of the 17th century, the Synod's grants served as the only means to train well-educated clergymen. The Synod and authorised people would find funds for studies, and the student would undertake to study well, and upon his return work for the good of the Church in a post assigned by the Synod, or refund the financial aid in the event of breach of the undertaking. The surviving commitment of Samuelis Teodoras Čaplinijus (Czaplinius) to the pastor of the Vilnius church in 1600 runs that in return for the stipend issued by the church to support his three-year-long education at a German university, he undertakes to work at the Vilnius church upon his return. ${ }^{13}$ In 1611, the Synod demanded that Adomas Rasijus (circa 1575-1627/8) either return to work at Vilnius School or refund

${ }^{13}$ LMAB RS, F. 40, f. 596, fo. 1, S.T. Čaplinijus' commitment to the seniors of Vilnius Reformed Church of 1600. 
the 300 florins spent on his training. ${ }^{14}$ In 1636, the Synod debated the assignment of the nobleman Matisevičius (Matisewicz), whose education abroad was funded by the pastor Bochvicas. The pastor delegated his decision-making authority to the Synod, and the Synod concluded that Matisevičius should be assigned to Kèdainiai School. ${ }^{15}$ In 1637, the Synod passed a resolution that all catechists whose foreign training was funded by its stipends should be employed at home rather than in a foreign country. ${ }^{16}$

Various methods were employed to accumulate education funds. First of all, the Synod collected gifts and contributions from financially well-off members of the community. It was entitled to certain sums of money and even estates with all their revenue through wills. For example, in 1606 Martynas Švoba made over his estate in Švobiškis to the Synod, and emphasised the funding of educational matters, and especially the training of Lithuanian alumni as a top priority. ${ }^{17}$ Often noblemen would allocate part of the revenue from their estate, for example that of a village or estate farm, to the Synod. The Synod would not take over their management, but would receive the income and accumulate it for the education of international alumni. Districts, the administrative units of Unitas Lituaniae, would also accumulate financial resources for the education of young people. The Synods of 1635 and $1653^{18}$ made a resolution that annual fees should be collected in the sessions of district communities, and the districts were put under the obligation to collect financial resources sufficient for the education of one alumnus from the district. S.B. Chylinski received one of these stipends, the Švoba stipend for Lithuanian alumni, ${ }^{19}$ and later qualified for the Synod's bursary for international studies. The donations for education received from the Biržai and Dubingiai branches of the Radvila family, patrons and other Calvinists, helped the Synod

${ }^{14}$ Akta synodów prowincialnych Jednoty Litewskiej 1611-1625 Monumenta Reformationis Polonicae et Lithuanicae (MRPL), ser. 4, zesz. 2 (Vilnius, 1915), pp. 1-2.

${ }^{15}$ LMAB RS, F. 40, f. 1157, fo. 448, records of the Lithuanian Calvinist Synod (LERSP) of 1636, canon 14.

${ }^{16}$ LMAB RS, F. 40, fo. 457, LERSP of 1637, canon 13.

${ }^{17}$ LNMMB, F. 93, b. 1314, fos. 1-7, Martynas Švoba's will of 22 July, 1606.

${ }^{18}$ LMAB RS, F. 40, b. 1157, LERSP, records of 1635, canon 5; ibid., b. 1136, fo. 174 , records of 1653 , canon 16 .

${ }^{19}$ MRPL, 4, zesz. 2, pp. 104-5. 
accumulate the largest funds. In 1623 and 1625, Kristupas Radvila allocated 6,000 złoty to the Synod, and prescribed that 2,000 złoty should be spent once-and-for-all on theological education for two international alumni. ${ }^{20}$

The second half of the 17 th century saw the rapid decline of Calvinism in the GDL and a significant decrease in the numbers of its followers as compared to the first half of the century. Although Calvinists became a religious minority, and it was obvious that the male line of the Radvila family was coming to an end, active members of Unitas Lituaniae were looking untiringly for ways to help the Church survive. At that time, the Synod had become the institution which was in possession of the financial resources allocated to it, parts of estates or their revenue, its own folwarks and acres and the possessions of the churches. A fair amount of funds reached the Synod from the benefices of the closed churches that were taken over by the Synod. Hence, the Calvinist Synod gradually accumulated financial resources and capital allocated to it or a particular church by those who had long been gone but by their last will had obliged posterity (often converts) to pay certain sums to the Synod. Under the circumstances, the Synod managed education funds centrally. From the middle of the 17th century, the organisation of international studies and the funding and screening of candidates were especially centralised in the hands of the Synod. As the decrease in Church membership led to a drop in patron funding, and fewer students could have their education funded by patrons, the Synod's grants assumed a gradual significance as a possibility to acquire a university education.

Around 1680, when the economy began to recover after the wars of the mid-17th century (between the Polish-Lithuanian Commonwealth and Sweden in 1655-60, and between the Polish-Lithuanian Commonwealth and Muscovy in 1655-67), the Synod undertook the initiative to strengthen the material facilities for the education of Lithuanian Calvinists. In 1680, it concluded that the education of young clergymen and the preparation for the translation of the Bible into Lithuanian were of the utmost importance to the stabilisation of the status of the Church. The same year, the Synod took the initiative to accumulate funds for the publication of the Bible in Lithuanian, ensure the steady payment of grants to international

${ }^{20}$ Ibid., p. 79, memoria 20, pp. 104-5, canon 19. 
alumni, and find funds for more grants for the education of Lithuanian Calvinists at foreign universities. The Synod authorised the 'action group' consisting of active secular supporters of the Church: Stefan z Radzimina Franckiewicz, the starosta of Slonim, Teofil Olędski, the under-chamberlain of Volkovysk, Stanisław Niezabitowski, the cup-bearer of Kalisz, Pawel Sienicki Zboncza, the podstoli of the Ruthenian Palatinate (in Poland), Michał Swiencicki, the podstoli of Mstislaw, and the superintendents of the districts of Belarus, Nowogrodek, Transvilia and Žemaitija, Krzysztof Žarnowiec, Jerzy Lutomirski, Mikalojus Minvydas and Danielius Mikolajevskis, to see to the abovementioned matters. ${ }^{21}$ First and foremost, the Synod and its authorised people made every effort to persuade the last Calvinist Radvila, Liudvika Karolina Radvilaite (Ludwika Karolina Radziwiłłówna), to resume the financial assistance to the Calvinist Church initiated by her ancestors. The Lithuanian Calvinist Synod and the superintendents of the Žemaitija and Transvilia districts struggled to achieve their aim: for several years they corresponded with L.K. Radvilaite, who lived either in Königsberg or in Neuburg, and explained in writing the situation of the Church in Lithuania and its essential needs. It was indicated that one of the Church's main needs was to increase funding for the education of students abroad. On 26 August 1687 Radvilaite agreed to allocate an annual revenue from her estates to the Synod. These resources enabled the Synod to educate young people at foreign universities for several hundred years. In order to support the education of three Synod grant holders at Königsberg University, she allocated 10,000 florins, which were invested in a folwark in the Duchy of Prussia and produced an annual income. ${ }^{22}$

The Synod also searched for financial resources abroad. Its instruction to Mikalojus Minvydas, the superintendent of Žemaitija, on his mission to England, to receive the remains of the financial aid for the publication of Chylinski's Bible and for the churches devastated in the war, directed him to apply to the king of England,

${ }^{21}$ LNMMB, F. 93, b. 20, fo. 72, LERSP, records of 1680, canon 23.

${ }^{22}$ LMAB RS, F. 40, b. 596, fo. 10-11, Liudvika Karolina Radvilaite’'s financial support to three alumni at Königsberg University, issued on 26 August 1697; ibid., fo. 26r-28v, financial accounts received by Stanislovas Nezabitauskis and sent to Königsberg in 1701 ; ibid., fo. $26 \mathrm{v}-30 \mathrm{v}$, receipts of the financial aid for the education of alumni received and sent to Königsberg on 24 February 1706 and 5 August 1707. 
the elector of Brandenburg, the parliament of the United Provinces of the Netherlands and the Landgrave of Hesse for financial support for the publication of the Bible in Lithuanian, and for Lithuanian students at the universities of their countries. ${ }^{23}$ A separate appeal was made to the queen of Denmark. Professor Sugiko Nishikawa, who has researched the attitude of the English elite of the mid-17th century towards the situation of Protestants in East and Central Europe, and the establishment of the Society for Promoting Christian Knowledge and its activities to support the declining Protestantism in the region, revealed the initiatives of certain heads of West European states to support the weakening Calvinist Church in East and Central Europe. ${ }^{24}$ Consequently, the efforts were mutual and the campaign bore certain fruit: even though there is no data whether the money collected in England reached the students, the Archive of the Synod contains an intermediary letter regarding the sustenance of alumni at Heidelberg University which Landgrave Karl of Hesse sent to the palsgrave on 20 April $1681,{ }^{25}$ and the elector Frederick William of Brandenburg's letters of 10 March 1681 and 17 November 1686 regarding the education of Lithuanian students at the universities of Frankfurt (Oder) and Königsberg, which suggest that long-term support for studies by young men from the GDL was provided. Karl of Hesse-Kassel (1654-1730) was a Calvinist, and his wife Amalia of Courland (1653-1711) was a granddaughter of Gotthard Kettler, the last grand master of the Livonian Order, who swore allegiance to the GDL in 1561. They were not ignorant about the GDL and the local Calvinist Church. Frederick William wrote: 'I have been informed that a great number of young people from Lithuanian and Žemaitijan communities aspire to study ... thus, we would like to provide for members of this nation in Frankfurt from the communal fund [Subjekta aus dieser Nation bey der mensa communi zu unterhalten] so that Lithuanians and Žemaitijans could be accepted and their number could increase. ${ }^{26}$ The concentrated efforts on both sides was not a singular occurrence, as the Synod strove to increase the number of

${ }^{23}$ LMAB RS, F. 40, b. 596, fo. 2-3, instruction issued by the Synod to Mikalojus Minvydas, the superintendent of the Transvilia district, on 6 July 1682.

${ }^{24}$ See article by S. Nishikawa, below pp. 51-9.

${ }^{25}$ LMAB RS, F. 40 , b. 596 , fo. 4 , a copy of the letter from the Landgrave of Hesse, Karl, to the Palsgrave, sent on 20 April 1681.

${ }^{26}$ Ibid., fo. 6r, 8r, the order of Frederick William, the elector of Brandenburg, to support alumni and a preceptor at Königsberg University, and the publication of the Bible in Lithuanian, issued on 17 November 1686. 
grant holders at foreign universities during the last quarter of the 17 th century and the first quarter of the 18th century. The elector of Brandenburg, who in 1701 became king of Brandenburg-Prussia, allocated 1,500 Prussian thalers annually to cover the expenses of Lithuanian students' tutors and education administrators at foreign universities, and granted another sum of money for the publication of S. Bitneris' Lithuanian translation of the New Testament. We are unaware of the landgrave of Hesse's reply in 1681, but in 1684 there were permanent stipends for students in Marburg, and Lithuanian alumni at Heidelberg University were trained in accordance with the order well-established over the course of a century. Students were regularly sent to the Netherlands, as the University of Leiden was among their favourites in the second half of the 17th century. At the very end of the century, in 1698, the Lithuanian Synod delegated Thomas Ramsey (a Scotsman who worked as a preacher in Kedainiai and was appointed superintendent of the Žemaitija district) to appeal to the elector of Brandenburg-Prussia, the queen of Denmark and Landgrave Karl of Hesse-Kassel for the initiation of a levy and for grants and financial support for Lithuanian alumni. In reply to requests presented in written form, Landgrave Karl did not introduce the levy, but assured that two scholarships, including full tuition, room and board, were and would be granted to Lithuanian students at Marburg. ${ }^{27}$ Several scholarships were available for students from the GDL at the University of Edinburgh as well.

Alongside the financial resources that were already in the Synod's possession, certain noble families and individuals, including the Rederis, the Mirskis, the Zviastovskis, the Oborskis, ${ }^{28}$ Petras Konarskis, the Putkameris, the Gruževskis, the Hlebavičius and others, would also provide financial aid for the education of young people in the second half of the 17th century.

Let us take a quick glance at the universities that the grant holders of the Synod would choose for their international training. The record books of European universities suggest that until the beginning of the 17th century, the majority of Lithuanian students were educated at the Protestant universities of Königsberg, Basel, Leipzig, Wittenberg, Altdorf, Heidelberg and Frankfurt (Oder). The outbreak of the Thirty Years' War (1618-1648) in the Holy Roman Empire

${ }^{27}$ LMAB RS, F. 40, b. 753, the reply of Landgrave Karl to the requests of the Synod, sent on 10 October 1698.

${ }^{28}$ Barycz, 'Obraz historyczny', p. 214. 
led to a change of destinations, and students from Lithuania for the most part flocked to universities in the Netherlands: Franeker (in Friesland) and Leiden. As we all very well know, one such Synod stipendiary was Chylinski. In the 1630s and 1640s, the University of Franeker was the most popular institution of higher education among Lithuanian Calvinists. At the beginning of the 17th century, the Synod allowed its grant holders to choose a university and allocated the necessary sum of money. The decline of the Reformation in Lithuania and a significant decrease in its membership made the Synod look for other forms for the organisation of international training: gradually, permanent places for alumni at certain universities were secured, though the germs of such organisation were observable already in the first half of the 17th century. This method for the organisation of education was established already after Chylinski's death. Elders and patrons of the Church made agreements with the leadership of the universities, and retained permanent places for alumni funded by the Synod. The Synod records ${ }^{29}$ of 1684 provided for the establishment of 15 places for alumni at foreign universities, with full coverage of tuition fees, room and board: four in Leiden, three in Marburg, four in Heidelberg, two in Frankfurt (Oder), two in Berlin (Joachimsthaler Grammar School), and in a couple of years three places at Königsberg University were added (in 1713 their number reached five, so the total number of places at universities abroad increased to 18). All these places for grant holders were purposive as the Synod kept repeating that the students should first and foremost acquire theological qualifications, others could become lawyers or military specialists. International training organised in the 17th century was supposed to supply local churches with Lithuanian-speakng pastors, thus as a rule, one of the alumni chosen for studies at Königsberg University had to have a good command of the language. Other canons suggested that sons of clergy who preached in Lithuanian had priority when receiving grants. ${ }^{30}$ The universities of Heidelberg and Franeker, and from the middle of the 17th century also Leiden, were usually chosen for theological studies. In 1726, young Lithuanian Calvinists were educated at the universities of Berlin, Frankfurt (Oder), Marburg, Königsberg, Leiden and Edinburgh. ${ }^{31}$

${ }^{29}$ LNMMB, F. 93, b. 20, fo. 133, LERSP records of 1684, canon 5.

${ }^{30}$ LNMMB, F. 93, b. 20, fo. 173, LERSP records of 1686, canon 12.

${ }^{31}$ LMAB RS, F. 40, fo. 9r-v, duplicate of the Synod's records of 1728. 
When education funds were centralised in the hands of the Synod of Unitas Lituaniae, the institution also supervised the screening of candidates. The selection of candidates was first of all the task of senior clergymen of districts and the rectors of Kedainiai, Slutsk and Zabludov grammar schools, but the Synod had to approve each candidate for alumni abroad and allocate scholarships in accordance with the financial resources in its possession. The Synod determined how long and at what institution a candidate should study, and monitored whether he had made up for the financial aid by working in a church on his return. In the second half of the 17th century, the synods held annual discussions to decide which students were entitled to study at which universities, and whether their studies should be prolonged, or whether they should be called home to work in the GDL. Usually successful candidates for international studies were sons of clergymen who decided to work as pastors. Thus, the Church ensured the training of a new generation of clergy. A couple of seculars were among those entitled to the Synod's grants. There were plenty of candidates to these positions; therefore, in the last decades of the 17th century, they were registered and the list was included in the protocol. However, due to a shortage of financial resources, delays in the collection of revenues from folwarks and estates and interest from loans, as well as inflation, which resulted in the devaluation of the currency, some places would sometimes remain vacant. The Synod and the superintendents of districts were obliged to see that foreign places for alumni were taken by wellprepared and capable young men. Until around the mid-17th century, when the entitlement to international studies was not strictly regulated, there were cases when 14 or 15-year-old boys who had not graduated from grammar schools applied for scholarships, thus the Synod passed canons providing for the allocation of grants to well-prepared candidates above 15 years of age..$^{32}$ In the second half of the 17th century, these regulations were followed, but obviously there were exceptions, which led to the resolution of the Synod of 1692, which ran that boys below 12 years of age and with insufficient preparation were not eligible for the positions. ${ }^{33}$ The resolutions of the Synod dating from the second half of the 17th century suggest that the majority of alumni would study for four years, yet

${ }^{32}$ LMAB RS, F. 40, b. 1136, fo. 278, LERSP, records of 1667, canon 5.

${ }^{33}$ LNMMB, F. 93, b. 20, fo. 288, LERSP, records of 1692, canon 19. 
there were cases when students requested to be withdrawn, as the studies were too demanding.

The stipends were secured first of all for the sons of Unitas Lituaniae pastors. They had the right to receive the Synod's grants, but a number of such candidates had their international studies funded by the district or a patron of the Church. Wealthier noblemen, who had a church founded by their ancesters on their estates, would allocate resources for the education of the new generation of pastors, though the Synod had the last word on clerical appointments to certain churches. For example, in 1681, Madam Oborska donated the sum of 2,000 złoty, part of which was used to cover the educational expenses of Daunoras (Downar), and the remaining part was promised to Jonas Božymovskis' (Borzymowski) son Mikalojus. ${ }^{34}$ A run through the lists of people who held the positions of senior clergymen and superintendents of Calvinist districts from the beginning of the 17 th century revealed that a number of them had studied at foreign universities; however, the ways of acquiring a university education at the beginning and at the end of the century were different.

At this point, there is no possibility to produce statistics on the numbers of Calvinist clergy who were entitled to international studies. However, it is possible to distinguish the families of pastors, especially those who worked throughout the entire 17th century. One of them was the Audzejevičius (Audziejewicz) family. Jonas Audzejevičius' thesis was published at the University of Franeker in 1647-1648 and 1652. ${ }^{35}$ Another one was the son of the co-elder of Vilnius (name not indicated), entitled to four years of studies at Königsberg and Franeker universities in 1676; yet another, Samuelis, received a scholarship in $1699 .{ }^{36}$

The education of members of the Božimovskis (Borzymowski) family was funded by Unitas Lituaniae throughout the 17th century. In 1631, Jonas Božimovskis (s 1610-1673) was not entitled to international studies, and had to wait until 1633. In 1637 his thesis were published at Franeker University. In 1638 he was withdrawn and returned to Lithuania. In 1653 he became the superintendent of the Žemaitija district, and was one of the compilers and Lithuanian translators of Knyga nobažnystès (1653). His son Jonas Božimovskis'

${ }^{34}$ LNMMB, F. 93, b. 20, fo. 97, LERSP, records of 1681, memoria 62.

${ }^{35}$ Postma and van Sluis, Auditorium Academiae, no. 50/1648.3a; no. 52/1651.20; no. 56/12-13.1.1648; no. 56/9.2.1652.

${ }^{36}$ LNMMB, F. 93, b. 20, fo. 398-400, LERSP, records of 1699, canons 13, 16. 
(1645-1687) theses were published in Franeker in $1665 .{ }^{37} \mathrm{He}$ continued the translation of the New Testament into the Lithuanian language started by his father, but failed to publish it under his name. His five children aspired to study abroad: Jonas and Danielius received scholarships, whereas Mikalojus, Samuelis and Kazimieras had to wait for other students to return home. ${ }^{38}$

The Progulbickis family was well-known in Unitas Lituaniae from the early 17th century. In 1611-1625, Povilas held the responsible position of the church asset manager and its representative in legal proceedings. Jonas Progulbickis was a well-educated pastor, appointed supervisor of the Kedainiai grammar school seminary in 1644, and the pastor of Kedainiai Lithuanian church in 1653. Another Jonas Progulbickis, most likely the son of the former, was educated at Franeker, enrolled there in 1645, and in 1648-1651 published his thesis under the name Johannes Progulbicki of Žemaitija. ${ }^{39}$ In 1668 , he was appointed deputy superintendent.

Education at Heidelberg and Altdorf in 1596-1600 and the doctor of theology degree awarded at Basel University in 1601 allowed Baltazaras Krosnevičius (Crosnievicius, Krosniewicz) to become a teacher at Vilnius Protestant Grammar school (1607-1611), pastor in Vilnius (1611), pastor of Biržai (1612-1623) and superintendent of the Transvilia District (from 1617). He was authorised by the Synod to organise the funding of international alumni and supervise their education. His connections with Matas Krosnevičius, who in 1636 enrolled in the University of Franeker as Matthias Krasnovicius (Krasnowiecki Lithuanus) and in 1636-1638 published his theology thesis there, ${ }^{40}$ were not established. In 1671 the Synod indicated that he was the rector of Kedainiai Grammar School. ${ }^{41}$ In 1672 he was succeeded in this office by Christophorus Taubmannus Trzebicki, another former student from the University of Franeker, who entered the institution in $1662 .{ }^{42}$

37 Postma and van Sluis, Auditorium Academiae, no. 64/1665.3a; no. 15, 31.

${ }^{38}$ LMAB RS, F. 40, b. 160, fo. 38-9; LNMMB, F. 93, b. 20, fo. 97, LERSP, records of 1681, memoria 57; ibid., protocol of 1687 , memoria 1-2, 3; ibid., fo. 164 , records of 1684 , memoria 61 .

${ }^{39}$ Postma and van Sluis, Auditorium Academiae Franekerensis, no. 34/1654.10; no. 50/1648/3a; no. 52/1651.11-14, 28-30

${ }^{40}$ Ibid. no. $28 / 1636.15 ; 28 / 1637.3 ; 28 / 1638.1$

${ }^{41}$ LMAB RS, F. 40, b. 1136, fo. 334, LERSP, records mission of 1671.

${ }^{42}$ Album studiosorum Academiae Franekerensis (1585-1511, 1816-1844), eds. S.J. Fockema Andreae, T.J. Meijer (Franeker [1968]), p. 188. 
The most prominent member of the Bitneris family was Samuelis (circa 1632-1710), superintendent of the Transvilia (1688) and Žemaitija (1698) districts, and translator of the Lithuanian New Testament published in Königsberg in 1701. On 31 May 1651 he enrolled in the University of Frankfurt (Oder). His sons Steponas and Jonas were the Synod's grant holders at Königsberg University from 1687, and his third son was promised international training upon his elder brothers' return. ${ }^{43}$

A different picture is observed when analysing the studies of the Minvydas family, which was close to Chylinski. Five members of the family held the office of superintendent in the 17th century, Chylinski's mother's maiden name was Minvydaite, yet the data on their international studies is scarcer than could be expected. It is known that in 1614 two members of the family held the office of superintendent: Mikalojus Minvydas was the superintendent of Žemaitija, and Stanislovas Minvydas of the Transvilia district. Stanislovas Minvydas' son Jonas entered Königsberg University on 9 October 1595. After graduation, he worked as a pastor in various churches in Lithuanian- speaking areas and, starting with 1624 , in sequence held the offices of the superintendents of Polesle, Žemaitija and Transvilia. ${ }^{44}$ Samuelis Minvydas (?-1660, most likely Jonas' son) was among the most prominent members of the Minvydas family in the 17th century, one of the initiators of the compilation and publication Knyga nobažnystess (1653) and one of the translators of its text. However, his name is absent from the records of the universities of Königsberg, Leiden, Frankfurt (Oder) and Franeker. His son Mikalojus, the superintendent of Žemaitija (from 1672), served for some time as Liudvika Karolina Radvilaite’'s court preacher in Königsberg, and shaped her opinion regarding the patronage of the Calvinist Church of Lithuania. In 1681 he went to England to attend to issues relating to the translation of Chylinski's Bible and seek financial aid for international alumni, and took letters to rulers of Europe. However, his name is not recorded in the matriculation books of any of the universities. He could have attended Königsberg University while in the city, without being officially listed as a student. The example of the Minvydas family suggests that in the 17th century most active Calvinist clergymen

${ }^{43}$ LNMMB, F. 93, b. 20, fo. 197, 1597. LERSP records of 1687 , canon 15 ; ibid., fo. 272, records of 1691 , canon 12 .

${ }^{44}$ LMAB RS, F. 40 , b. 160 , fo. 171 , digest of the Synod's acts. 
and teachers made every effort to enter educational institutions; however, scholarships of the Lithuanian Synod were the prime and most consistent way to acquire a university education. Members of such renowned families of clergymen of Unitas Lituaniae as the Skrockis, Jordanas, Musonijus and Rečinskis were among those whose education at the universities of Western and Central Europe was funded by the Synod.

Summarising the role of the international studies organised by the Lithuaniuan Calvinist Church in the cultural life of the country, it can be stated that the institute facilitated cultural contacts, and simultaneously promoted the infusion of new ideas in the evolution of Lithuanian culture. Even though the numbers of international alumni were not comparable to those of graduates of Vilnius University, there was a renewable group of clergymen and professionals educated in a different mentality to that of the Jesuit university. Students, especially those who studied in the Netherlands, would share the experience of a well-organised economy and an ascendant country. As an analysis of the lists of library books suggests, returning students would bring back books which they read and disseminated, together with knowledge and philosophy different to what was about to settle in Lithuania. The most significant results of the cultural activities of the Synod's grant holders in the 17 th century can be divided into the following groups: 1) Training of teachers with a university education for Lithuanian Calvinist schools. 2) Nurturing of projects to improve the system of education in Lithuania. Among them were treatises by Adomas Rasijus (ca 1575-1627/8), a graduate of Gdańsk Academic Grammar School and Königsberg University, and a teacher at Biržai School and Kèdainiai Grammar School. He wrote about the importance of merchants in society, and proposed projects for the improvement of the education system to establish academic gymnasiums with special syllabi for the nobility and merchants in Lithuania. ${ }^{45}$ 3) Chylinski's translation of the Bible into Lithuanian in the middle of the century; an understanding of the importance of the Lithuanian language as a written language and

${ }^{45}$ I. Lukšaitè, 'Adomas Rasijus - Lietuvos kultūros veikèjas ir jo traktatai: (1. Adomo Rasijaus biografija ir kūryba)', MADA, 1989, vol. 1 (106), pp. 103-114; eadem '(2. Visuomenès filosofijos problematika A. Rasijaus kūryboje)', MADA, 1989, vol. 3 (108), pp. 84-96; eadem '(3. A. Rasijaus ekonominès pažiūros)', $M A D A, 1989$, vol. 4 (109), pp. 68-79; eadem '(4. A. Rasijaus projektai švietimo srityje)', MADA, 1989, vol. 4 (109), pp. 80-90. 
the language of the Holy Scripture in the promotion of faith; an acquaintance with the translation, text and comments of the Dutch Statenbijbel. 4) Even though Chylinski's translation of the Bible was not appreciated duly, the precedent consolidated the ambition to have the Bible published in the Lithuanian language. The case of Chylinski's Bible served as an important stimulus to accomplish the translation of Samuelis Bitneris' New Testament. In the light of the precedent, the Synod made every effort to find the financial resources for its publication in 1701 . The New Testament published in 1701 was the first part of the Holy Scripture in the Lithuanian language widely used by the Lithuanian Calvinists. 5) Clergymen who studied in Leiden in the second half of the 17th century drafted the translation of comments on the Dutch Statenbijbel in the Polish language. In 1689, the Synod decided to assign the translation of the 'Dutch Bible' with comments into the Polish language to Danielius Mikolajevskis (Mikołajewski). The translators, former students from Leiden University who had a good command of Dutch, had to be provided with the newest edition of the Bible. Among them were: John Paterson, doctor of theology and co-elder of Žemaitija, Jonas Jordanas, rector of Slutsk Grammar school, Samuelis Liutomirskis, rector of Kedainiai Grammar School and the son of Danielius Mikalojevskis, the superintendent of the Žemaitija district, whose name was also Danielius and who had just returned from his studies in the Netherlands. In 1690, the Synod discussed methods of translation and the publication of comments on the Dutch Bible, and decided to send a letter to the pastor of Leiden College asking for three copies of the newest edition of the Bible. The Synod stated that the superintendent of Žemaitija, Danielius Mikolajevskis, had already submitted the translation of part of the comments. ${ }^{46}$ It is obvious that studies at the universities of the north Netherlands, and especially Leiden, helped them form the qualification standard for the translation of the Bible and its comments and evaluate them. In 1697, the Synod appointed the Lithuanian-speaking reviewers of Bitneris' translation of the New Testament. One of them was John Paterson, also listed as a translator of the Dutch Bible into the Polish language.

Unfortunately, Lithuanian culture failed to duly appreciate these creations. Several reasons are accountable for this: the Calvinist

${ }^{46}$ LNMMB, F. 93, b. 20, fo. 228-9, LERSP, records of 1689, canon 2; ibid., fo. 245 , records of 1690 , canon 5 ; ibid., fo. 366 , canon 6 . 
Church was the church of a religious minority, subjected to repression in the second half of the 17th century; and the unfavourable social and political situation in Lithuania. However, graduates from foreign universities, as a minor but solid group of intellectuals, constantly refreshed the Lithuanian mentality with ideas different from those that were about to prevail in the country.

\section{Author Details}

Professor Ingè Lukšaite is a senior research officer at the Department of the History of the Grand Duchy of Lithuania at the Lithuanian Institute of History. Her main areas of research are the history of culture, social and religious movements, the history of historical sciences, and source studies.

Address: Department of the History of the Grand Duchy of Lithuania, Lithuanian Institute of History, Kražių 5, LT-01108, Vilnius, Lithuania.

E-mail: luksaite@gmail.com

\section{LIETUVOS DIDŽIOSIOS KUNIGAIKŠTYSTĖS EVANGELIKŲ REFORMATU BAŽNYČIOS IR SINODO STIPENDININKAI UŽSIENIO UNIVERSITETUOSE XVII A.}

Santrauka

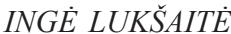

Nagrinėjamas Lietuvos Didžiosios Kunigaikštystès evangelikų reformatų bažnyčios (Unitas Lituaniae) aukštojo mokslo studijų organizavimas XVII a.: XVII a. pirmoje pusejje reformacijos silpnejjimo laikotarpiu ir XVII a. antroje pusėje, kai evangelikai tapo tikybine mažuma. Remiamasi Unitas Lituaniae sinodo archyvo dokumentais. Nustatyta, kad i užsienio universitetus buvo siunčiami jaunuoliai privačiomis lëšomis, distriktuose surinktomis ir sinodo sukauptomis. Tiriamas evangelikų reformatų sinodo užsienio alumnų instituto susidarymas, kuris tapo reformatų švietimo sistemos dalimi. Už gautas lèšas studijavusieji privalèjo atidirbti Lietuvoje ir ten, kur juos skyrè sinodas. Amžiaus pradžioje jų daugiausia buvo evangeliškuose Karaliaučiaus, Bazelio, Leipcigo, Vitenbergo, Altdorfo, Heidelbergo ir Frankfurto prie Oderio universitetuose; XVII a. pirmoje puseje ir viduryje daug studentų iš Lietuvos telkèsi Franekerio ir Leideno universitetuose. Amžiaus pabaigoje stipendijos su visu išlaikymu gautos Leidene - 4, Marburge - 3, Heidelberge - 4, Frankfurte prie Oderio - 2, Berlyne (Joachimstalerio gimnazijoje) - 2, Karaliaučiuje -3 . Nuolat ir organizuotai siunčiami reformatų studentai per šimtmetį brandino, nors ir negausią, bet stabiliai veikiančią protiniu darbu duoną pelniusių grupelę. Dauguma Lietuvos reformatų bažnyčios vadovaujančiujų, Kėdainių ir Slucko gimnazijų rektoriai ir dauguma mokytojų buvo baigę užsienio universitetus. Susidare reformatų kunigu giminès (Božimovskiai, Bitneriai, Progulbickiai, Krosnevičiai (Krosnovieckiai), Minvydai ir kt., kurių kelios kartos buvo studijavusios užsienio universitetuose. Šimtmeti veikęs sinodo užsienio alumnų institutas sudare galimybes plètoti kultūrinius kontaktus, o kartu ir skatino naujovių issruvas Lietuvos kultūros 
raidoje. Svarbiausios jų buvo: sudarè aukšto išsilavinimo bažnyčios dvasininkų, gimnaziju pedagogų grupes; subrandino Adomo Rasijaus (apie 1575-1627/1628) projektus koreguoti visuomenès sandarą ir tobulinti Lietuvos švietimos sistemą: ikurti Lietuvoje kilmingujų ir pirklių akademines gimnazijas su specializuotomis programomis; paskatino XVII a. viduryje $\mathrm{S}$. B. Chylinskị išversti Bibliją i lietuvių kalbą Franekeryje ir Londone; buvo suvokta lietuvių kalbos, kaip rašto kalbos ir kaip šv. Rašto kalbos reikšmè, o kartu jos vaidmuo tikejjimo diegimui; tai suteikè impulsą $1701 \mathrm{~m}$. pabaigti Naujojo Testamento vertimą i lietuvių kalbą ir ji išleisti 1701 m.; kelios studentų kartos buvo susipažinusios su olandų Statenbijbel vertimu, tekstu ir komentarais; tai paskatino projektuoti olandiškos Statenbijbel tekstų ir komentarų vertimą i lenkų kalbą. Užsienio universitetuose išsilavinimą igijusieji buvo, nors ir negausi, bet tvirta kitokio mąstymo, nei pradèjo įsigalèti Lietuvos Didžiojoje Kunigaikštystėje, srovelè Lietuvos mentaliteto padangèje. 